\title{
Supraclavicular Surgical Approach for Thoracic Outlet Syndrome: 10 Years of Experience
}

\section{Torasik Ģıkış Sendromunda Supraklaviküler Yaklașım: 10 Yallık Tecrübe}

\author{
Sedat DALBAYRAK ${ }^{1}$, Onur YAMAN² ${ }^{2}$ Mesut YILMAZ ${ }^{3}$, Teyfik YILMAZ $^{4}$ \\ ${ }^{1}$ Neurospinal Academy, Istanbul, Turkey \\ ${ }^{2}$ Tepecik Education and Training Hospital, Clinic of Neurosurgery, Izmir, Turkey \\ ${ }^{3}$ Neurospinal Academy, Istanbul, Turkey \\ ${ }^{4}$ Dicle University, School of Medicine, Department of Neurosurgery, Diyarbakır, Turkey
}

Corresponding Author: OnurYAMAN / E-mail: dronuryaman@yahoo.com

\begin{abstract}
AIM: Symptoms of thoracic outlet syndrome (TOS) may be vascular, neurological or combined symptoms involving both. Treatment of TOS is generally conservative. Surgical treatment is required when radiological results indicate anatomical abnormality. This study aims to present the surgical outcomes of TOS patients treated with supraclavicular approach via microsurgery.

MATERIAL and METHODS: 41 patients with thoracic outlet syndrome were rewieved retrospectively. The pain was determined using both on visual analogue scale (VAS) and Oswestry score both in the preoperative and postoperative period. All patients underwent electromyography including brachial plexus, ulnar and median nerves. Computed Tomography (CT) angiographic examination was applied dynamically with required manoeuvres.

RESULTS: Post-op VAS scores were recorded as 0.8 for the arm, 0.6 for the shoulder and 0.5 for the neck, while pre-op VAS scores were 6.3 for the arm, 6.0 for the shoulder and 5.2 for the neck. Post-op Oswestry disability index (ODI) average was found as 14,2, while this figure was 67,4 during the pre-operative period.
\end{abstract}

CONCLUSION: Accurate patient selection is imperative for increasing the success of TOS surgery. Microscopic TOS surgery yields satisfactory results with smaller incision, safer surgery and a lower rate of complication.

KEYWORDS: Thoracic outlet syndrome, Supraclavicular approach, Surgery

öz

AMAÇ: Torasik çıkış sendromu (TÇS) vasküler, nörolojik ya da her iki yapıya bası sonucu ortaya çıkabilir. TÇS tedavisi genellikle konservatiftir. Radyolojik olarak tespit edilen anomali durumunda cerrahi tedavi gereklidir. Bu çalışmanın amacı, supraklaviküler yol ve mikroşirürjkal teknikle ameliyat edilen TÇS tanılı hastaların cerrahi sonuçlarını bildirmektir.

YÖNTEM ve GEREÇLER: TÇS nedeni ile opere edilen 41 hasta geriye dönük olarak incelendi. Hastaların klinik durumları görsel ağrı skoru (VAS) ve Oswestry skorlaması (ODI) ile cerrahi öncesi ve sonrası değerlendirildi. Hastaların tamamına cerrahi öncesi brakial pleksus, ulnar ve median sinirleri kapsayacak şekilde elektromyografik inceleme ve gerekli manevralar yapılarak dinamik bilgisayarlı tomografik anjiografileri (BTA) yapıldı.

BULGULAR: Cerrahi öncesi kol, omuz ve boyun ağrısı VAS değerleri sırasıyla 6,3; 6,0; 5,2 iken cerrahi sonrası kol, omuz ve boyun ağrısı VAS değerleri sırasıyla 0,8; 0,5; 0,5 olarak tespit edildi. ODI cerrahi öncesi ortalama 67.4 iken bu değer cerrahi sonrası 14.2'e indi.

SONUÇ: TÇS için doğru hasta seçimi cerrahi başarı şansını artıracaktır. Mikroskop eşliğinde yapılan TÇS daha küçük açıım, daha emniyetli cerrahi ve daha az komplikasyon oranı ile ile yüz güldürücü sonuçlar vermektedir.

ANAHTAR SÖZCÜKLER: Torasik çıkış sendromu, Supraklaviküler yaklaşım, Cerrahi

\section{INTRODUCTION}

Thoracic Outlet Syndrome (TOS) refers to a set of complex symptoms that occur as a result of compression of the neural and vascular structures leading to the upper extremity. Symptoms of the syndrome may be vascular, neurological or combined symptoms involving both $(1,14,25)$. Although the syndrome was initially named after compressive aetiologies such as scalenus anticus, costoclavicular, hyperabduction, cervical rib and first thoracic rib, Peet used the term "Thoracic Outlet Syndrome" to define the compression of neurovascular structures at the thoracic outlet (15). TOS can be broken into three sub-groups, namely the neurogenic TOS that is caused by the compression of the nerves of brachial plexus; vascular TOS that is caused by the compression of subclavian artery or vein; and the group which involves combined symptoms including both (5). The neurogenic type of TOS is more common clinically than vascular TOS.

Treatment is generally conservative, unless the radiology results indicate structural abnormality. Surgical treatment is required when radiological studies indicate anatomical 
abnormality, especially adventitious fibrous band. Surgical treatment is also required for patients with symptoms lasting for more than two months; patients with symptoms that hamper daily activity; patients for whom conservative treatment fails to yield a satisfactory result; and patients with objective neurologic compression (19).

This study aims to present the surgical outcomes of TOS patients treated with supraclavicular surgery.

\section{MATERIAL and METHODS}

The study involves a retrospective analysis of 41 cases operated upon being diagnosed as Thoracic Outlet Syndrome in a period of 10 years.

\section{Patient Evaluation}

The patients were clinically evaluated based on their past medical history and neurological examination. Light touch, hot-cold sensation and two point discrimination tests were conducted and results were recorded in detail. Adson, Wright and Roos provocation tests were applied on all patients. Preop neck, shoulder and arm pain suffered by patients, were evaluated based on visual analogue scale with scores 0 to 10 (0-no pain, 10-maximum pain). The pain was determined using Oswestry score both in the preoperative and postoperative period ( $0 \%$ to $20 \%$, does not constitute a significant problem in patient's life, $80 \%$ to $100 \%$ - bed-bound patient)

As a routine, the patients underwent plain radiography for their cervical vertebrae, shoulders and ribs.

During the preoperative period, all patients underwent electromyography including brachial plexus, ulnar and median nerves, and subclavian artery-vein Doppler USG to differentiate vascular pathologies. Furthermore, Computed Tomography (CT) angiographic examination was applied dynamically with required manoeuvres.

\section{Surgical Technique}

The patient under general anaesthesia is put in a supine position on the operating table, and pillow is placed to extend cervical and thoracic vertebrae. Upper and lower parts of the clavicle are sterilized, after the patient's head is turned contralaterally (Figure 1). Linear incision $(3 \mathrm{~cm})$ is made starting from the posterior border of the Sternocleidomastoid muscle to the clavicle (Figure 2). Blunt dissection enables the surgeon to reach brachial plexus. After being divided off the first rib, the anterior scalene muscle is mobilized 3 to $4 \mathrm{~cm}$ cranially. After dissecting the periosteum and muscles of the first rib, the plexus is carefully retracted. The middle scalene muscle is then exposed. Middle scalene muscle fibers are dissected at the posterior side of the first rib. In the meantime, pleura are pushed back. A 3-4 cm part of the first rib is resected using Kerrison and bone rongeur. A large space is left behind the clavicle after the rib is removed. Compression of neurovascular structures is checked by abduction and external rotation of the arm. Brachial plexus neurolysis is performed with microscopic surgery. Any band or soft tissue compressing the lower trunk is thereby checked. Presence of fibrosis at the trunks or chords should be checked by using a microscope. The purpose of surgery is to ensure that the proximal and distal parts of neural tissue regain its normal appearance.

\section{RESULTS}

\section{Age/Gender}

The patients' age varied between 16 and 46 years, while the average age was 32 years. Out of 41 patients, 11 were male (26.8\%), and 30 were female (73.2\%). Two of the 41 patients were physicians and 9 were health workers.

\section{Clinical Features}

Arm pain was the most common complaint that made patients see a doctor. A total of 39 patients suffered from arm pain $(95 \%)$, while 25 patients suffered from shoulder pain and 22 from neck pain (60\%, and 53\%, respectively). Although 39 patients complained about weakness in the arm, arm weakness was actually detected only in 10 patients (24\%). 8

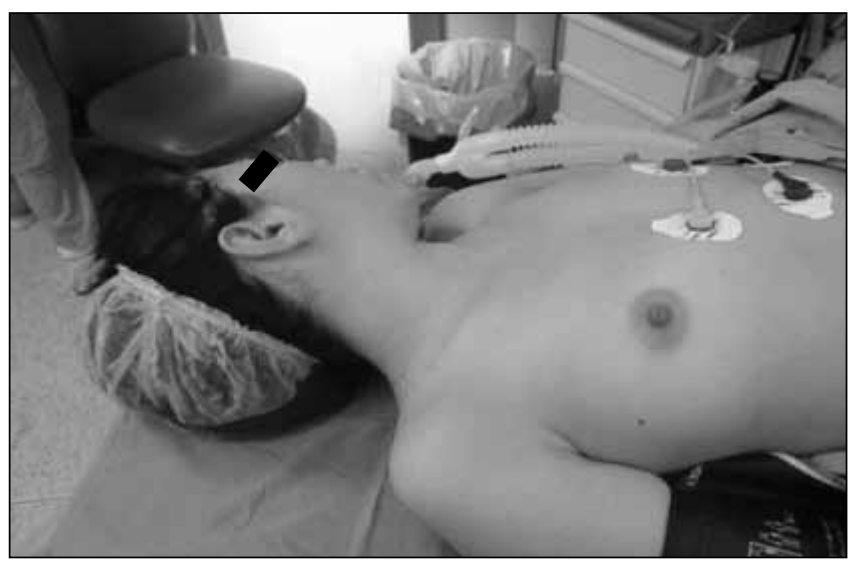

Figure 1: Positioning the patient before surgery. The patient's head should be turned contralaterally.

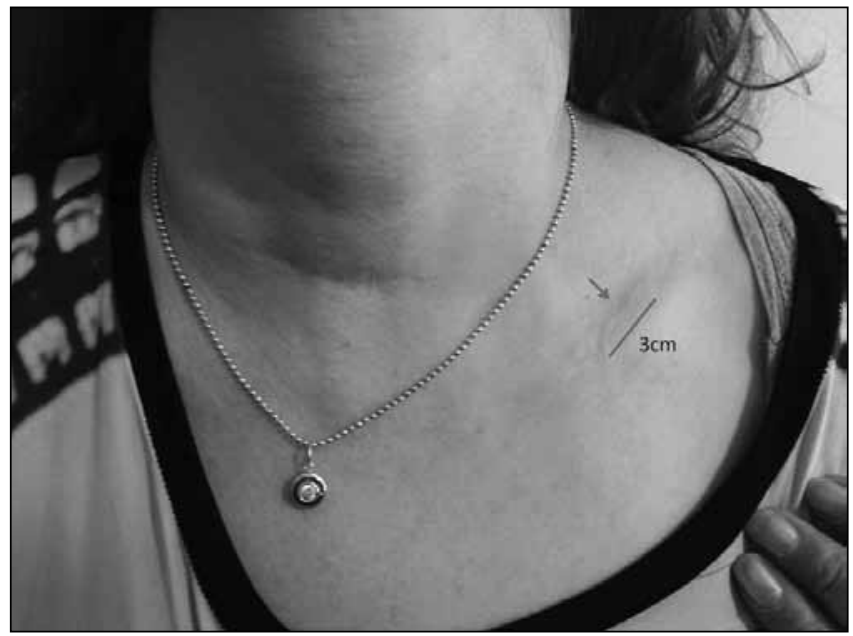

Figure 2: Skin incision scar after TOS surgery with supraclavicular method. 
Table I: Summary of Patient Complaints

\begin{tabular}{|l|c|c|}
\hline Complaint & $\begin{array}{c}\text { Number of } \\
\text { Patients }\end{array}$ & Rate (\%) \\
\hline Arm pain & 39 & 95 \\
\hline Numbness and paresthesia & 34 & 82 \\
\hline Shoulder pain & 25 & 60 \\
\hline Neck pain & 22 & 53 \\
\hline Arm weakness & 10 & 24 \\
\hline Hand atrophy & 8 & 19 \\
\hline
\end{tabular}

patients had hand atrophy (19\%), and 34 patients complained about numbness in the arm and fingers 34 (82\%). Patient complaints are summarized in Table I.

\section{Pathology}

Preoperative radiological examination of 41 patients indicated cervical rib or long C7 transverse process in 38 of them. Suprascapular procedure was applied with approximately 4 to $5 \mathrm{~cm}$ incisions and microsurgery was adopted. Anterior scalene muscle was incised in all cases. Fibrous bands were divided, whereby both vascular and neural decompression were obtained.

\section{Pain Levels}

Follow up period of patients varies between 4 to 118 months (average 49.4 months). Post-operative VAS scores were recorded as 0.8 for the arm, 0.6 for the shoulder and 0.5 for the neck, while pre-operative VAS scores were 6.3 for the arm, 6.0 for the shoulder and 5.2 for the neck. Average post-operative Oswestry disability index (ODI) was found as 14.2, while this figure was 67.4 during the pre-operative period.

\section{Complications}

Superficial skin infection was observed in two patients, who were treated with antibiotics after the surgery. However, recurrence was observed in two of the three cases without bone resection. These two cases were re-operated and the bone was resected.

\section{DISCUSSION}

Subclavian artery, vein and brachial plexus pass through three anatomically narrow passages until they arrive at the axillary area. These narrow passages can be listed as the following: interscalene triangle, which is bordered anteriorly by the anterior scalene muscle, posteriorly by the middle scalene muscle, and inferiorly by the first rib; the area between the first rib and the clavicle (costoclavicular space); and the area between the pectoralis minor muscle tendon and coracoid process of the scapula $(16,23)$.

Real TOS patients are those with cervical rib, rudimentary first rib, clavicle and first rib fractures, bone anomalies such as long C7 transverse process and soft tissue anomalies (congenital myofascial band or ligament, post-traumatic fibrous band). Although some series reported that $10 \%$ to $90 \%$ of patients diagnosed as and treated for Thoracic Outlet Syndrome had cervical rib, imaging techniques did not reveal any pathology for such patients diagnosed as $\operatorname{TOS}(2,5,8,9,20)$.

Neck, shoulder and arm pain and paresthesia are the most common symptoms caused by compression of the brachial plexus. In the later stages, motor weakness and muscle atrophy may be observed $(7,18)$. Arterial thoracic outlet syndrome is more frequently observed in middle-aged men. The most common cause is the cervical rib $(4,12)$. Weak pulse and claudication in the arm and hand are observed due to arterial compression. Venous thoracic outlet syndrome is caused by the obstruction of subclavian vein in the thoracic outlet. Neurogenic TOS is observed in $50 \%$ of the venous type TOS cases. Incidence rate is $75 \%$ for the right subclavian vein, while it is $25 \%$ in the left subclavian vein. Typical findings are pain in the arm and fingers together with oedema, coldness, heat and various changes in the skin such as ulceration and gangrene $(4,12)$.

TOS should be considered for patients with neck and arm pain, and it can be diagnosed during patient examination by the help of provocation tests such as the Adson test, costoclavicular test, hyperabduction test and abduction external rotation test.

Determining bone pathology through plain radiography including cervical vertebrae, clavicle and the ribs will be useful for potential TOS patients (Figure 3). If any pathology is detected in the patient, $C T$ is a useful way of examining the status of bone structure. (Figure 4A, B) Since the symptoms may be confused with those of cervical disc disease, cervical MRI should be used for differential diagnosis. Electromyography

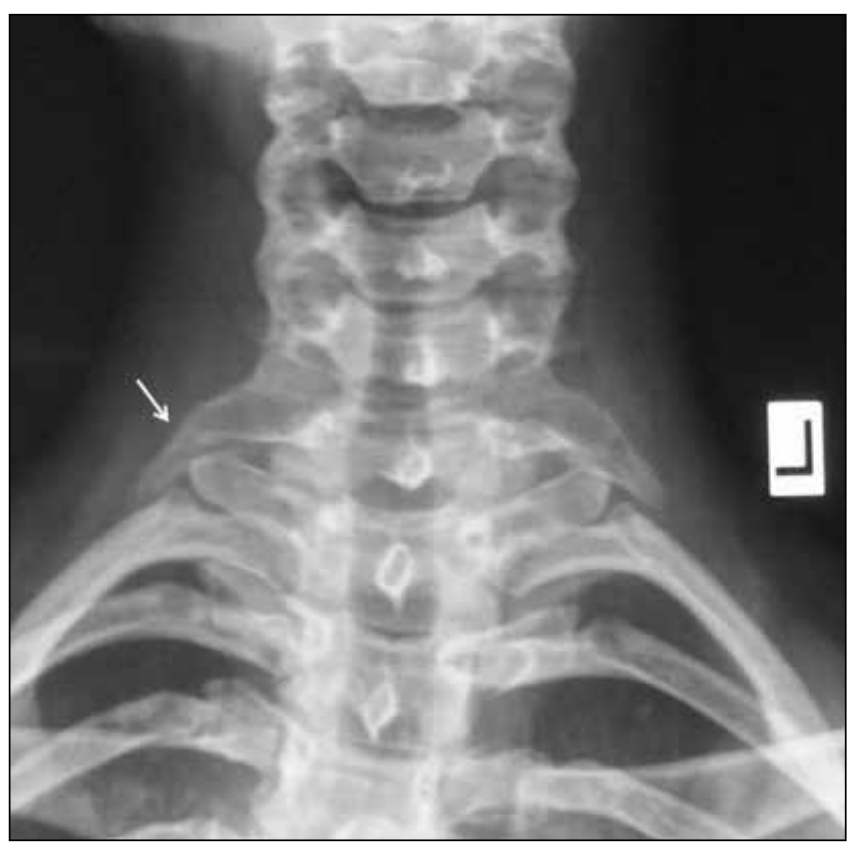

Figure 3: Bilateral cervical rib image displayed in the plain radiography of a 16-year-old patient with right arm and neck pain (indicated with an arrow). 


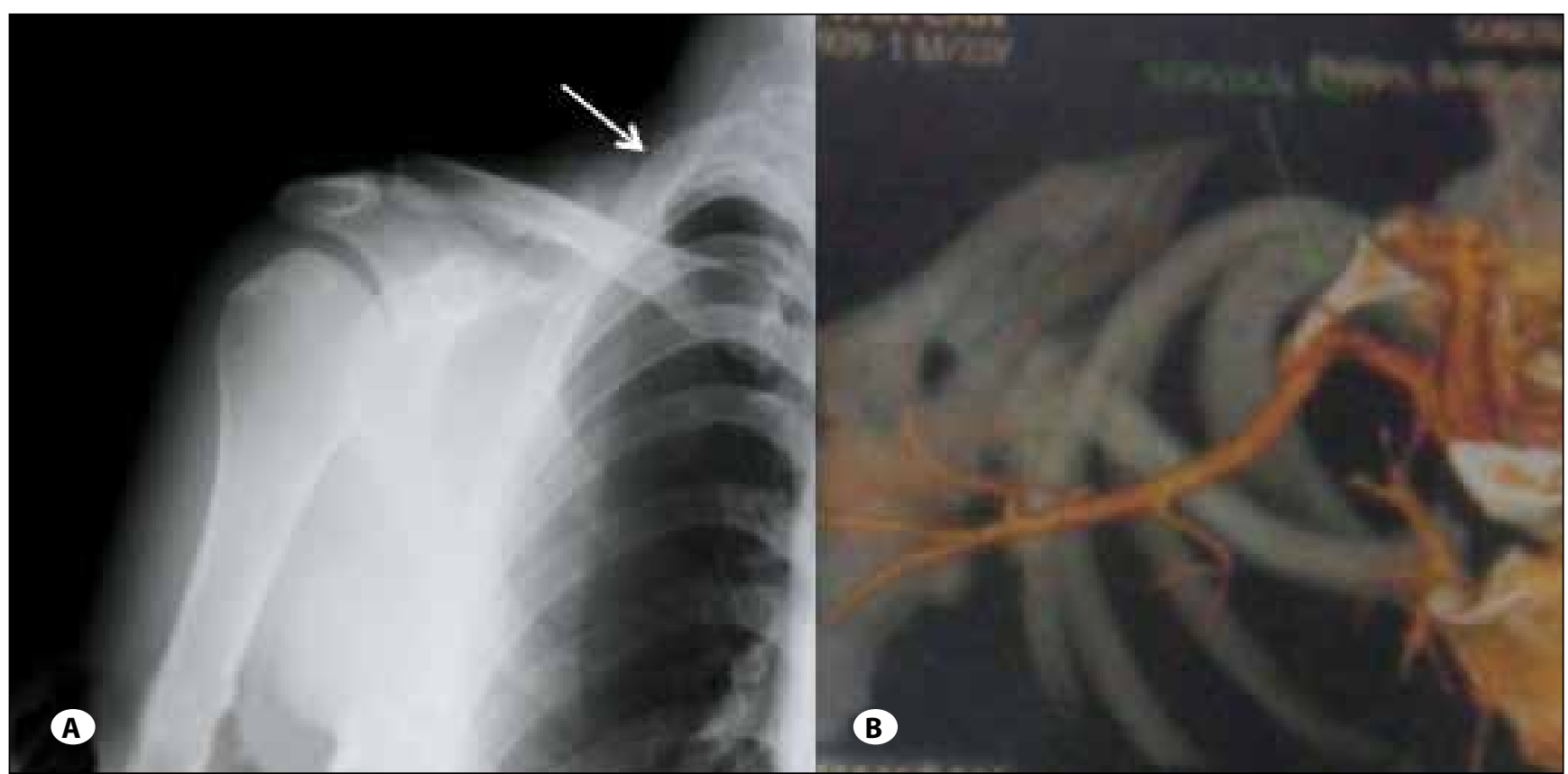

Figure 4: A) Cervical plain radiography of a 33-year-old patient with neck, right shoulder and right arm pain, showing the cervical rib on the right B) axial CT section of the same patient, showing the relation of right subclavian artery and the cervical rib.

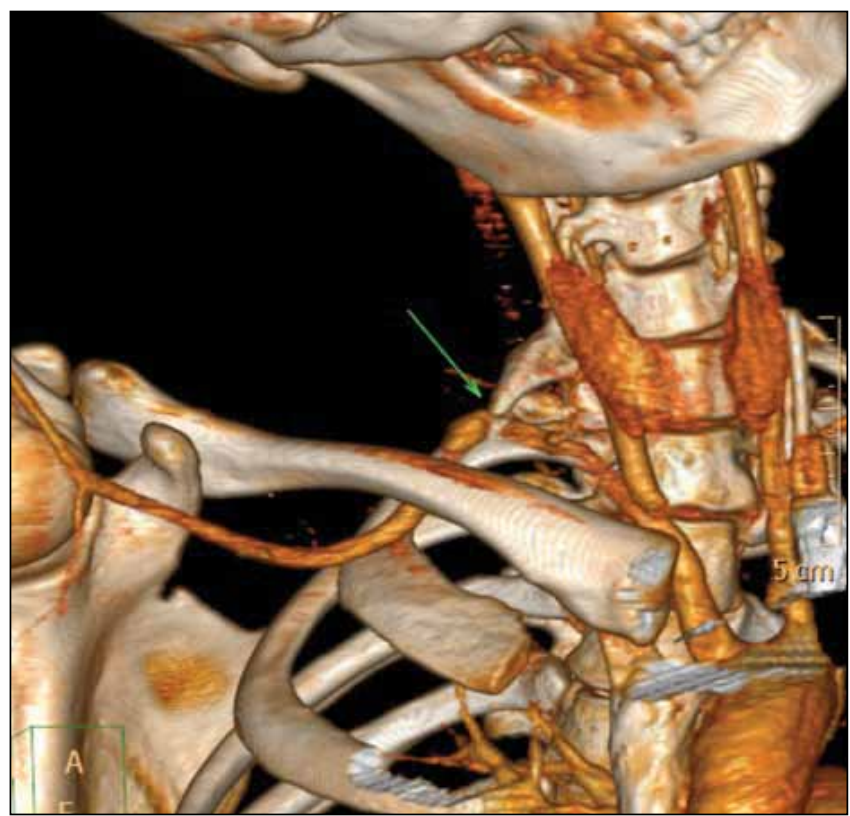

Figure 5: Compression causing $80 \%$ stenosis in the right subclavian artery as shown in the right lateral CT angiography of patient with neck and right arm pain (green arrow).

must be used to check ulnar nerve transmission in patients. In cases suspected of vascular lesions Doppler, and when required angiography, should be used (4). Dynamic CT angiography is highly valued in evaluating vascular TOS (Figure 5,6).

Conservative treatment may be adopted for patients without vascular findings (13). Surgery should be considered for symptoms that persist despite conservative treatment $(8$, 9). Techniques defined for the surgical treatment of TOS are supraclavicular approach, infraclavicular approach, transaxillary approach and posterior subscapular approach (17). Traditionally, transaxillary intervention is adopted for the TOS that is associated with compression of lower plexus, while supraclavicular approach is preferred for the involvement of upper plexus. Roos first described rib resection with transaxillary intervention (18). One disadvantage of transaxillary intervention is that congenital fibromuscular bands are hard to see and arterial reconstruction is difficult, when required (3). One important complication of transaxillary approach surgery is the $20 \%$ recurrence rate $(23,24)$. The main complications of transaxillary surgery include superficial and deep infections, pneumothorax, vascular injuries and neural damage. Supraclavicular intervention is reported to provide better exposure to anatomical structures and ease of first rib resection $(10,21,22)$. Much better surgical visibility, the possibility of arterial reconstruction and less neurological deficit can be listed as the main advantages of supraclavicular intervention over the transaxillary intervention (6). Maxey et al. reported that supraclavicular intervention is safer and superior to other methods of intervention (11). Recurrence is one of the important complications in the surgical treatment of TOS. Recurrent symptoms may be observed due to reossification in the periosteum bed after rib resection (6). Incidence rate of post-op recurrence is $63 \%$ and recurrence is usually observed during the first 6 months (6). In our patient series, recurrence was observed in three cases during the post-operative period, and among them, two were within the first 6 months, and one within 9 months Effectiveness of supraclavicular surgical procedure was displayed in recurrent 


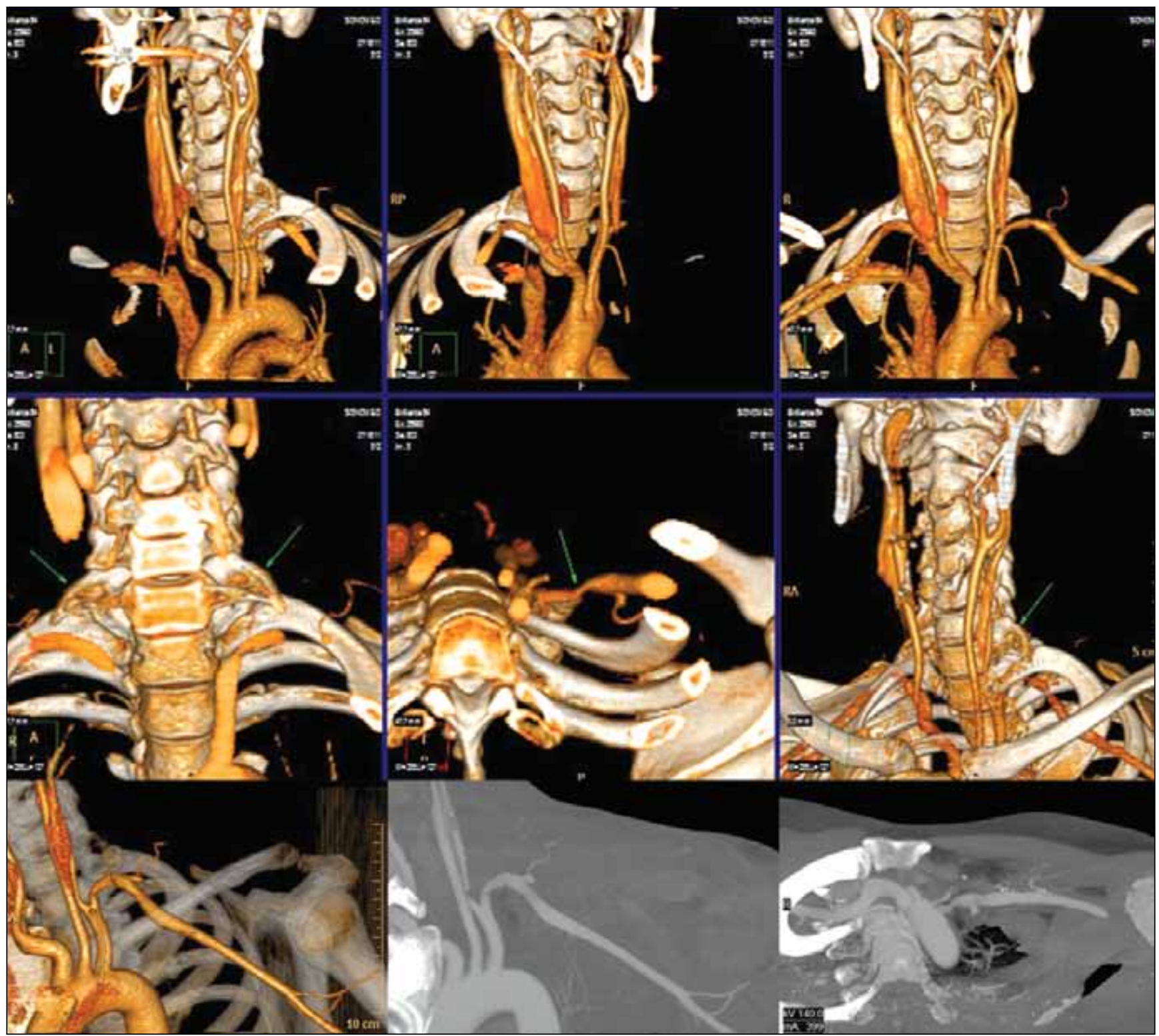

Figure 6: Dynamic CT angiography of bilateral cervical rib and subclavian vascular compression on the left side. Patient had positional vertigo due to compression of the left vertebral artery.

TOS (1). Bone resection yields better results in cases of bone irritation such as the cervical rib.

The most common complication in the thoracic outlet syndrome surgery is the pneumothorax. Some series reported a rate of $85 \%$ for pneumothorax, and it is usually observed in the transaxillary intervention (18). One important hint to reduce complications involves avoiding sharp dissection as much as possible and maximum protection of pleura during surgery. The probability of damaging subclavian artery or vein is 1 to $2 \%$. There is a risk of tearing subclavian artery, which is especially fragile during rib resection. Therefore, maximum protection should be provided to vascular structures during bone resection (18). Nerve damage may occur especially during the incision of scalene muscle. Frequency of damaging frenic nerve during the incision of anterior scalene muscle is $1 \%$. Inferior trunk of brachial plexus may be injured especially in the transaxillary intervention $(21,22)$. Another rare $(0.25 \%)$ complication, which is $50 \%$ mortal, if untreated, is the chylothorax that is associated with injury to the thoracic duct $(21,22)$.

In this study, the "microsurgical technique" was adopted with a small incision (with an average of 3 to $5 \mathrm{~cm}$ ), and use of retractor for surgical site visibility was minimized. Coaxial light, magnification and three-dimensional imaging features of the microscope were used in the dissection of neural and vascular structures, especially in the exploration of brachial plexus. Thereby, fibrous bands were completely exposed and osseous structures below and behind the brachial plexus 
could be safely resected. Total rib resection may not always be possible in supraclavicular surgical approach due to disarticulation. In such cases partial resection may be applied.

\section{CONCLUSION}

It is hard to treat TOS for neurosurgeons. Surgical treatment is required for patients with vascular component and persistent symptoms despite conservative treatment. Accurate patient selection is imperative for increasing the success of surgery. Microscopic TOS surgery yields satisfactory results with smaller incision, safer surgery and a lower rate of complication.

\section{REFERENCES}

1. Ambrad-Chalela $\mathrm{E}$, Thomas $\mathrm{Gl}$, Johansen $\mathrm{KH}$ : Recurrent neurogenic thoracic outlet syndrome. Am J Surg 187: 505-510, 2004

2. Davies AH, Walton J, Stuart E, Morris PJ: Surgical management of the thoracic outlet compression syndrome. Br J Surg 78: 1193-1195, 1991

3. Fulford PE, Baguneid MS, Ibrahim MR, Schady W, Walker MG: Outcome of transaxillary rib resection for thoracic outlet syndrome: A 10 year experience. Cardiovasc Surg 9:620-624, 2001.

4. Gillard J, Perez-Cousin M, Hachulla E, Remy J, Hurtevent JF, Vinckier L, Thevenon A, Duquesnoy B: Diagnosing thoracic outlet syndrome: Contribution of provocative tests, ultrasonography, electrophysiology, and helical computed tomography in 48 patients. Joint Bone Spine 68:416-424, 2001.

5. Huang JH, Zager EL: Thoracic outlet syndrome. Neurosurgery. 55:897-902, 2004

6. Kashyap VS, Ahn SS, Machleder HI: Thoracic outlet neurovascular compression: Approaches to anatomic decompression and their limitations. Semin Vasc Surg 11:116-122, 1998

7. Landry GJ, Moneta GL, Taylor LM Jr, Edwards JM, Porter JM: Long-term functional outcome of neurogenic thoracic outlet syndrome in surgically and conservatively treated patients. J Vasc Surg 33:312-319, 2001

8. Leffert RD: Complications of surgery for thoracic outlet syndrome. Hand Clin 20: 91-98, 2004

9. Leffert RD, Perlmutter GS: Thoracic outlet syndrome: Results of a 21-year experience with clinical diagnosis and treatment of 259 TOS patients with 282 transaxillary first rib resections. Clin Orthop Rel Res 368:66-79, 1999

10. Lepantalo M, Lindgren KA, Leino E, Lindfors O, von Smitten K, Nuutinen $\mathrm{E}$, Tötterman $\mathrm{S}$ : Long-term outcome after resection of the first rib for thoracic outlet syndrome. Br J Surg 76: 1255-1256, 1989
11. Maxey TS, Reece TB, Ellman PI, Tribble CG, Harthun N, Kron IL,Kern JA: Safety and efficacy of the supraclavicular approach to thoracic outlet decompression. Ann Torac Surg 76:396-399, 2003

12. Molina JE: Combined posterior and transaxillary approach for neurogenic thoracic outlet syndrome. J Am Coll Surg 187: 39-45, 1998

13. Nakatsuchi $Y$, Saitoh S, Hosaka M, Matsuda S: Conservative treatment of thoracic outlet syndrome using an orthosis. J Hand Surg Br 20:34-39, 1995

14. Novak CB, Collins ED, Mackinnon SE: Outcome following conservative management of thoracic outlet syndrome. J Hand Surg Am 20:542-548, 1995.

15. Peet RM, Hendriksen JD, Anderson TP, Martin GM: Thoracic outlet syndrome: Evaluation of the therapeutic exercise program. Proc Staff Meet Mayo Clin 31:281-287, 1956

16. Pollack EW: Surgical anatomy of the thoracic outlet syndrome. Surg Gynecol Obstet 150:97-103, 1980

17. Reilly LM, Stoney RJ: Supraclavicular and other operative approaches to thoracic outlet syndrome. In: Bell PRF, Jamieson CW, Ruckley CV, (eds), Surgical Management of Vascular Diseases. London: WB Saunders, 1992:977-984

18. Roos DB: Congenital anomalies associated with thoracic outlet syndrome: Anatomy, symptoms, diagnosis, and treatment. Am J Surg 132:771-778, 1976

19. Sanders RJ, Monsour JW, Gerber WF, Adams WR, Thompson $\mathrm{N}$ : Scalenectomy versus first rib resection for treatment of the thoracic outlet syndrome. Surgery 85:109-121, 1979

20. Steiner $\mathrm{H}$ : Roentgenologic manifestations and clinical symptoms of rib abnormalities. Radiology 40:175-178, 1943

21. Thompson JF, Jannsen F: Thoracic outlet syndromes. Br J Surg 83: 435-436, 1996

22. Thompson RW, Petrinec D: Surgical treatment of thoracic outlet compression syndromes: Diagnostic considerations and transaxillary first rib resection. Ann Vasc Surg 11: 315-323, 1997

23. Urschel HC Jr, Cooper JD: Atlas of thoracic surgery. New York: Churchill-Livingstone, 1995

24. Urschel HC Jr, Razzuk MA: Neurovascular compression in the thoracic outlet: Changing management over 50 years. Ann Surg 228:609-617, 1998

25. Wright $D$, Jennings PR: Thoracic outlet syndrome. JAAPA 18:57-58, 2005 